J. Product. \& Dev., 15(2): 185 - 200 (2010)

\title{
EFFECT OF FOOD PROCESSING ON RESIDUES OF DINICONAZOLE, ETOXAZOLE AND IMIDACLOPRID IN STRAWBERRY FRUITS
}

\author{
Mohamed Y. Hendawi*; Ahmed A. Romeh** and Tarek M. Mekky*** \\ * Faculty of Agriculture, Plant Protection Department, Zagazig University, Zagazig, \\ Egypt \\ ** Plant Production Department, Efficient Productivity Institute, Zagazig University, \\ Zagazig, Egypt \\ ***Food \& Dairy Technology, Zagazig University, Zagazig, Egypt \\ Corresponding author. Tel.: 020553712971; fax: 020552364612. \\ E-mail address: ahmedromeh2006@yahoo.com
}

\section{ABSTRACT :}

Strawberry fruits were sprayed with imidacloprid, diniconazole and etoxazole at the recommended rates of application. The effect of processing on removal of tested pesticide residues from strawberry fruits were studied. According to their half-life (t1/2) values, strawberry fruits can be safely harvested for human consumption or for processing purposes 14,7 and 3 days after the spraying of imidacloprid, diniconazole and etoxazole, respectively. The removal ratio of imidacloprid, diniconazole and etoxazole residues in strawberries were in the range of 9.9-30.55\%, 10.0-29.52\% and $15.0-46.67 \%$, respectively, by washing with tap water.The average amount of imidacloprid, diniconazole and etoxazole residues in strawberry fruits, juice, syrup under cold and hot break were greatly decreased compared with those in unwashed strawberry fruits. Moreover, the amount of residues of the three tested pesticides was more greatly decreased in strawberries syrup under hot break than cold break.

Pesticide residues were concentrated into jam and increased to higher levels than strawberry juice. A change in physical and chemical properties of strawberry fruits and products was related mainly to the processing operations.

Keywords : Strawberries, diniconazole, etoxazole , imidacloprid, processing operations.

\section{INTRODUCTION}

Strawberries (Fragaria ananassa Duch.) are of great interest because they are a good source of vitamin $\mathrm{C}$, anthocyanins and flavonols. Among fruits, they have one of the highest antioxidant activities (Cordenunsi et al., 2005). 
The risk to human health resulting from the widespread application of pesticides for many decades is well known. In recent years, attention has been focused on food safety. This is especially true for pesticide residues, and degradation rates on strawberries subjected to field treatments (Stensvand and Christiansen 2000 ,Falqui-Cao et al. 2001, Wennrich et al. 2001, Angioni, et al. 2004) and post harvest processing (Will and Kru" ger 1999). Commercial and household processing such as washing, juicing, s, blanching, concentrating can reduce residue level in food, then reduce impact on human health (Abou-arab, 1999; Byrne and Pinkerton, 2004 and Yun et al., 2011). Etoxazole, 2-(2,6-difluorophenyl)-4-[4-(1,1-dimethylethyl)-2-ethoxyphenyl]4,5- Dihydrooxazole, a new organofluorine pesticide, was produced by Sumitomo Chemical Co. Ltd. (Osaka, Japan) in 1998 and developed worldwide as a new-generation acaricide for citrus, apples, grapes, vegetables, flowers, cotton, and tea. Etoxazole is an alternative to carbamates, organochlorines, and other miticide and works by inhibiting molting (Shibuya, 1999). Etoxazole showed moderately rapid biodegradation in a variety of soils with a mean halflife of 20.5 days. Imidacloprid, 1-[(6-chloro-3-pyridyl)-methyl]- 2nitroimidazolidin, represents a modern potent insecticide group, chloronicotinyl that interacts like nicotine, epibatidine and nereis toxin analogues with the postsynaptic nicotinic acetylcholine receptor (Bai et al., 1991; Tomizawa and Yamamoto, 1993). Imidacloprid has excellent systemic properties, which makes it suitable for seed, soil and foliar treatment (Wamhoff and Schneider, 1999). Diniconazole (E-(R,S)-1-(2,4-dichlorophenyl)- 4,4-dimethyl-2-(1H-1,2,4-triazol1-yl)-pent- 1-en-3-ol) is a broad-spectrum systemic fungicide. The compound exhibits steroid demethylation inhibitors, acting mainly on the vegetative stages of fungi by blocking the mycelial growth either inside or on the surface of the host plant (Mohamed et al., 2007).

The present investigation was undertaken to study the level and persistence of imidacloprid, diniconazole and etoxazole in strawberry following field treatments, washing, processing to juice, syrup under cold and hot break and jam.

\section{MATERIALS AND METHODS}

\section{Field experiments}

The investigation was carried out on strawberries (Fragaria ananassa) grown in plots located in Deer El-Mullak, Abou-Hammad province, Sharkia governorate, Egypt. Common agricultural and fertilization practices were used. The field experiment included three replicate plots of 10 rows per treatment and each plot was separated by a five row belt. The pesticides were applied once and the control plot left without application of the pesticide. 
At the maturation of strawberry fruits, spraying separately with imidacloprid $20 \% \mathrm{SC}$, diniconazole $5 \% \mathrm{EC}$ and etoxazole $10 \% \mathrm{SC}$ formulation at the recommended rates of application ,i.e., 100, 7 and $8 \mathrm{~g}$ a.i. per feddan were carried out. The amount of formulated pesticide required for 1 feddan was diluted in $400 \mathrm{~L}$ of water and applied to plants using a hand sprayer. The strawberry fruits were harvested at a suitable stage maturity, either for consumption or for processing.

\section{Sampling and processing}

Representative strawberry fruit samples were taken $1 \mathrm{~h}$ after pesticide application to determine the initial deposits of each pesticide. Afterward the fruits were collected at intervals 1, 3, 7 and 14 days after application. Random samples of about $1500 \mathrm{~g}$ were collected from the three plots of each treatment. Different samples of strawberries juice, syrup under cold / hot and jam were prepared as described in Fig 1. Samples of $50 \mathrm{~g}$ of fresh strawberries, $50 \mathrm{~g}$ of washed fruits, $50 \mathrm{~mL}$ of juice, $50 \mathrm{~mL}$ of syrup and $50 \mathrm{~g}$ of jam were taking to determination the Pesticide residues of the three studied compounds.

\section{Chemical analysis:}

Total soluble solids (TSS), Titritable acidity (TA), pH,Ascorbic acid (AA), Reducing, non-reducing and total sugars and Total protein was determined method according to A.O.A.C.(1995).

\section{Residues Analysis}

Imidacloprid was extracted from the fruits samples and processing products with acetonitrile then partitioning into chloroform. The organic extract was evaporated to dryness, then subjected to adsorption chromatography over florisil (60-80 mesh) using acetonitrile :methanol(95:5 V/V). The organic fraction was evaporated to dryness, rinsed with HPLC grade methanol and filtered $(0.2 \mu \mathrm{m})$ for direct HPLC analysis. Samples were determined according to Sanyal et al. (2006). After extraction and clean-up using HPLC (with a UVdetector set at the wavelength $270 \mathrm{~nm}$ ). A C18 column was used and the mobile phase was a mixture of methanol/ water $(60: 40, \mathrm{v} / \mathrm{v})$. The flow rate was 1.0 $\mathrm{mL} / \mathrm{min}$. Under these conditions the retention time of imidacloprid was 3.36 min . Diniconazole and etoxazole were extracted from the fruits samples and processing products by homogenizing for two minutes with $100 \mathrm{ml}$ acetone. After being homogenized, mixture was filtered through glass wool and volume of filtrate was measured. $40 \mathrm{ml}$ of filtrate was taken to separation funnel. After adding mixture of $50 \mathrm{ml}$ methylene chloride and petroleum ether (1:1) to separation funnel, which was shaken gently and organic phase taken to glass funnel. The organic fraction was evaporated to dryness, rinsed with HPLC grade 


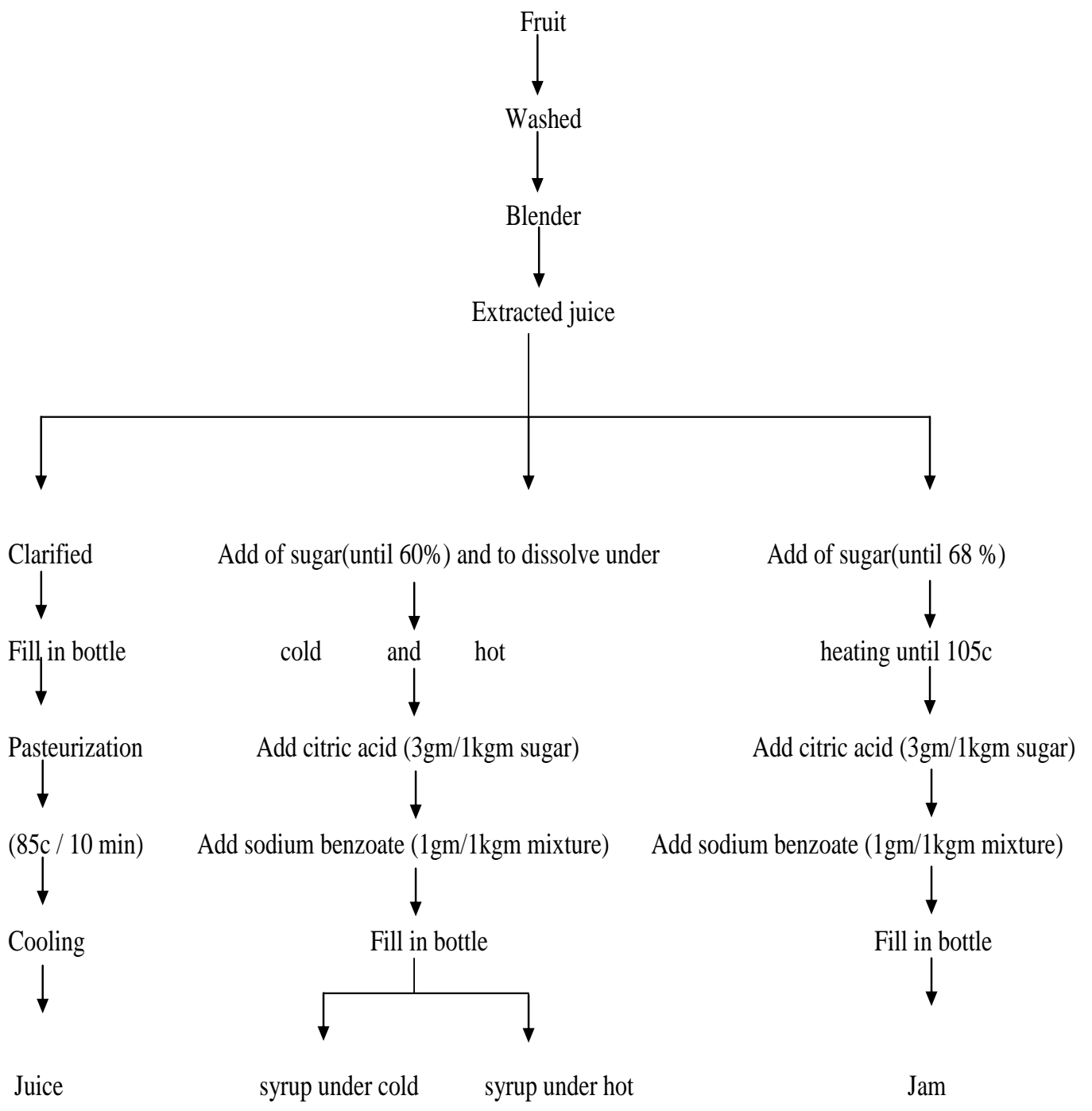

Figure 1. Samples preparation diagrams ( schema) of strawberries juice, syrup under cold / hot and jam.

methanol and filtered $(0.2 \mu \mathrm{m})$ for direct HPLC analysis.(Luke, et al 1981).

Etoxazole residue was dissolved in $1.0 \mathrm{ml}$ of acetonitrile and an aliquot $(50 \mu \mathrm{l})$ was analysed by HPLC with a UV-detector set at the wavelength $270 \mathrm{~nm}$. A C18 column was used and the mobile phase was a mixture of methanol/ water $(70: 30, \mathrm{v} / \mathrm{v})$. The flow rate was $0.5 \mathrm{~mL} / \mathrm{min}$. Under these conditions the retention time was $17.6 \mathrm{~min}$. 
Diniconazole residue was determined according to Ramadan etal .,1992 by HPLC with a UV-detector set at the wavelength $254 \mathrm{~nm}$. A C18 column was used and the mobile phase was a mixture of methanol/ water (80:20, $\mathrm{v} / \mathrm{v})$. The flow rate was $0.7 \mathrm{~mL} / \mathrm{min}$. Under these conditions the retention time $7.6 \mathrm{~min}$.

The rate of degradation $(\mathrm{K})$ and Half-life $(\mathrm{t} 1 / 2)$ were obtained from the following equation by Gomaa and Belal (1975) .

\section{Recovery assays:}

Samples of untreated strawberries fruits were fortified with appropriate volumes of standard solutions to reach concentrations of $1 \mu \mathrm{g} / \mathrm{gm}$. The samples were allowed to settle for $30 \mathrm{~min}$ before extraction and then processed according to the above procedure. Recovery data were obtained from four replicates for each concentration.

\section{Statistical analysis:}

Analysis of variance (ANOVA) was carried out for the obtained data according to the method of Waller and Duncan (1969).

\section{RESULTS AND DISCUSSION}

The results of the initial deposits, dissipation percentage, and half-life values of the three pesticides in strawberry fruits are presented in Tables 1, 2 and 3. The average initial deposits of imidacloprid, diniconazole and etoxazole in the unwashed strawberry fruits $1 \mathrm{~h}$ after application were found to be 3.6 $\pm 0.11,0.27 \pm 0.09$ and $0.36 \pm 0.019 \mathrm{mg} / \mathrm{kg}$, respectively. Fourteen days after application, imidacloprid, diniconazole and etoxazole residues were dissipated in the unwashed strawberries to reach $0.11 \pm 0.01,0.007 \pm 0.001$ and $0.02 \pm 0.0005$ $\mathrm{mg} / \mathrm{kg}$. Its dissipation rates were $96.94,99.63$ and $94.44 \%$ at the end of 2 weeks of application. The dissipation of pesticide residues in/on crops depends on climatic conditions, type of application, plant species, dosage, interval between application, and time of harvest (Khay et al., 2008). The half-lives of imidacloprid, diniconazole and etoxazole were found to be $72.48,24$ and $96 \mathrm{hrs}$ for strawberry fruits, respectively. Kousik, et al. (2010) reported that Half-life 
Table1. Residues of imidacloprid, in strawberry fruits and products as affected by processing stages

\begin{tabular}{|c|c|c|c|c|c|}
\hline \multirow[b]{2}{*}{ Treatments } & \multicolumn{5}{|c|}{ Days after treatment } \\
\hline & Initial* & 1 & 3 & 7 & 14 \\
\hline \multicolumn{6}{|c|}{ Unwashed strawberry fruits } \\
\hline mean $\pm \mathrm{SD} \quad(\mathrm{mg} / \mathrm{kg})$ & $3.6 \pm 0.11$ & $2.4 \pm 0.22$ & $1.6 \pm 0.25$ & $0.77 \pm 0.31$ & $0.11 \pm 0.01$ \\
\hline$\%$ loss & 0.0 & 33.33 & 55.56 & 78.61 & 96.94 \\
\hline \multicolumn{6}{|c|}{ Washed strawberry fruits } \\
\hline mean $\pm \mathrm{SD}(\mathrm{mg} / \mathrm{kg})$ & $2.5 \pm 0.18$ & $1.8 \pm 0.3$ & $1.3 \pm 0.4$ & $0.64 \pm 0.41$ & $0.1 \pm 0.02$ \\
\hline$\%$ loss by washing & 30.55 & 25.0 & $(18.75)$ & $(16.88)$ & 9.09 \\
\hline \multicolumn{6}{|l|}{ Strawberry juice } \\
\hline \multirow[t]{2}{*}{ mean $\pm \mathrm{SD} \quad(\mathrm{mg} / \mathrm{ml})$} & & & $1.2 \pm 0.39$ & $0.52 \pm 0.17$ & \\
\hline & & & 25.0 & 32.45 & \\
\hline \multicolumn{6}{|l|}{ Strawberry cold syrup } \\
\hline \multirow[t]{2}{*}{ mean $\pm \mathrm{SD} \quad(\mathrm{mg} / \mathrm{ml})$} & & & $0.97 \pm 0.15$ & $0.43 \pm 0.11$ & \\
\hline & & & 39.37 & 44.16 & \\
\hline \multicolumn{6}{|l|}{ Strawberry hot syrup } \\
\hline \multirow[t]{2}{*}{ mean $\pm \mathrm{SD}(\mathrm{mg} / \mathrm{ml})$} & & & $0.92 \pm 0.26$ & $0.38 \pm 0.13$ & \\
\hline & & & 42.5 & 50.64 & \\
\hline \multicolumn{6}{|l|}{ Strawberry Jam } \\
\hline mean $\pm \mathrm{SD}(\mathrm{mg} / \mathrm{kg})$ & & & $1.32 \pm 0.24$ & $0.65 \pm 0.32$ & \\
\hline $\mathrm{T} 1 / 2 \mathrm{~h}$ & 72.48 & & & & \\
\hline Rate of degradation & $3.13 \times 10-6$ & & & & \\
\hline MRLs & 0.5 & & & & \\
\hline
\end{tabular}


Table 2. Residues of diniconazole in strawberry fruits and products as affected by processing stages

\begin{tabular}{|c|c|c|c|c|c|}
\hline \multirow[b]{2}{*}{ Treatments } & \multicolumn{5}{|c|}{ Days after treatment } \\
\hline & Initial* & 1 & 3 & 7 & 14 \\
\hline \multicolumn{6}{|c|}{ Unwashed strawberry fruits } \\
\hline mean $\pm \mathrm{SD}(\mathrm{mg} / \mathrm{kg})$ & $0.27 \pm 0.09$ & $0.17 \pm 0.08$ & $0.055 \pm 0.02$ & $0.038 \pm 0.01$ & $0.007 \pm 0.001$ \\
\hline$\%$ loss & 0.00 & 37.04 & 79.63 & 85.93 & 99.63 \\
\hline \multicolumn{6}{|c|}{ Washed strawberry fruits } \\
\hline mean $\pm \mathrm{SD}(\mathrm{mg} / \mathrm{kg})$ & $0.19 \pm 0.13$ & $0.13 \pm 0.07$ & $0.046 \pm 0.03 \quad 0$ & $0.034 \pm 0.01$ & $0.009 \pm 0.002$ \\
\hline$\%$ loss by washing & 29.52 & 23.52 & 16.36 & 10.52 & 10 \\
\hline \multicolumn{6}{|l|}{ Strawberry juice } \\
\hline \multirow[t]{2}{*}{ mean $\pm \mathrm{SD} \quad(\mathrm{mg} / \mathrm{ml})$} & & & $0.035 \pm 0.016$ & $0.02 \pm 0.01$ & \\
\hline & & & 36.37 & 47.37 & \\
\hline \multicolumn{6}{|l|}{ strawberry cold syrup } \\
\hline \multirow[t]{2}{*}{ mean $\pm \mathrm{SD}(\mathrm{mg} / \mathrm{ml})$} & & & $0.04 \pm 0.012$ & $0.025 \pm 0.01$ & \\
\hline & & & 27.28 & 34.21 & \\
\hline \multicolumn{6}{|l|}{ strawberry hot syrup } \\
\hline \multirow[t]{2}{*}{ mean $\pm \mathrm{SD}(\mathrm{mg} / \mathrm{ml})$} & & & $0.025 \pm 0.005$ & $0.016 \pm 0.0$ & 013 \\
\hline & & & 54.55 & 51.51 & \\
\hline \multicolumn{6}{|l|}{ strawberry Jam } \\
\hline \multicolumn{3}{|l|}{ mean $\pm \mathrm{SD}(\mathrm{mg} / \mathrm{kg})$} & $0.09 \pm 0.0111$ & $1 \quad 0.054 \pm 0$. & .07 \\
\hline $\mathrm{T} 1 / 2 \mathrm{~h}$ & 24 & & & & \\
\hline Rate of degradation & $5.33 \times$ & $10-7$ & & & \\
\hline MRLs & 0.0 & & & & \\
\hline
\end{tabular}


Table 3. Residues of etoxazole in strawberry fruits and products as affected by processing stages

\begin{tabular}{|c|c|c|c|c|c|}
\hline \multirow[b]{2}{*}{ Treatments } & \multicolumn{5}{|c|}{ Days after treatment } \\
\hline & Initial* & 1 & 3 & 7 & 14 \\
\hline \multicolumn{6}{|c|}{ Unwashed strawberry fruits } \\
\hline mean $\pm \mathrm{SD}(\mathrm{mg} / \mathrm{kg})$ & $0.36 \pm 0.019$ & $0.26 \pm 0.012$ & $20.15 \pm 0.005$ & $0.09 \pm 0.006$ & $0.02 \pm 0.0005$ \\
\hline$\%$ loss & 0.0 & 27.78 & 58.33 & 75.0 & 94.44 \\
\hline \multicolumn{6}{|c|}{ Washed strawberry fruits) } \\
\hline mean $\pm \mathrm{SD}(\mathrm{mg} / \mathrm{kg})$ & $0.192 \pm 0.021$ & $0.15 \pm 0.01$ & $0.1 \pm 0.008$ & $0.07 \pm 0.002$ & $0.017 \pm 0.0001$ \\
\hline$\%$ loss by washing & 46.67 & 42.3 & 33.33 & 22.22 & 15.0 \\
\hline \multicolumn{6}{|l|}{ Strawberry juice } \\
\hline \multirow[t]{2}{*}{ mean $\pm \mathrm{SD}(\mathrm{mg} / \mathrm{ml})$} & & & $0.03 \pm 0.0045$ & $0.02 \pm 0.009$ & \\
\hline & & & 88.46 & 86.67 & \\
\hline \multicolumn{6}{|l|}{ strawberry cold syrup } \\
\hline \multirow[t]{2}{*}{ mean $\pm \mathrm{SD}(\mathrm{mg} / \mathrm{ml})$} & & & $0.08 \pm 0.006$ & $0.03 \pm 0.0003$ & \\
\hline & & & 69.23 & 80. & \\
\hline \multicolumn{6}{|l|}{ strawberry hot syrup } \\
\hline \multirow[t]{2}{*}{ mean $\pm \mathrm{SD}(\mathrm{mg} / \mathrm{ml})$} & & & $0.06 \pm 0.009$ & $0.01 \pm 0.00$ & \\
\hline & & & 76.92 & 93.33 & \\
\hline \multicolumn{6}{|l|}{ strawberry Jam } \\
\hline mean $\mathrm{SD}(\mathrm{mg} / \mathrm{kg})$ & & & $0.158 \pm 0.006$ & $0.117 \pm 0.0$ & 008 \\
\hline $\mathrm{T} 1 / 2 \mathrm{~h}$ & 96 & & & & \\
\hline Rate of degradation & $4.56 \times 10-7$ & & & & \\
\hline MRLs & 0.2 & & & & \\
\hline
\end{tabular}


(T1/2) of imidacloprid were observed to be 2.31 and 2.18 days, respectively when applied at 42 and $84 \mathrm{~g}$ a.i. ha-1 in brinjal.

As shown in Tables 1, 2 and 3, it is evident that washing the pesticide treated strawberry fruits with tap water induced considerable relative reductions in pesticide residues within the range of $9.9-30.55 \%, 10.0-29.52 \%$ and 15.0 $46.67 \%$ for imidacloprid, diniconazole and etoxazole, respectively. The effects of different food processing techniques on pesticide residue levels in fruits washing by a non-toxic solution can decrease the concentration of pesticide residues in the vegetable and fruit samples. (Angioni et al., 2004, Kaushik et al. 2009, Chai and Tan, 2010; Shweta et al., 2010 and Keikotlhaile et al., 2010). Washing has been found to reduce pesticides that are loosely attached to the surface of the fruits or vegetables (Abou-Arab, 1999). The removal extent depended on the physical and chemical properties of the pesticide method of application, as well as the nature of the cultivated plant. Residues may get dried on the surface, adsorbed bound to waxy material in the outer portion of the fruit or vegetable, or translocated into the inner tissues of the plant with increasing difficulty of removal (Ripley and Edgington, 1983 ). The removal of pesticide residues by washing has also been found to depend on the age of the chemical (Guardia-Rubio et al., 2007).

As shown in Tables 1, 2 and 3, the MRLs maximum residue levels $(\mathrm{mg} / \mathrm{kg})$ of imidacloprid, diniconazole and etoxazole in strawberry fruits was 0.5 , 0.05 and $0.2 \mathrm{mg} / \mathrm{kg}$, respectively as adopted by the FAO/WHO Codex Alimentarius Commission (CAC , 2008). It can thus be concluded that strawberry fruits can be safely harvested for human consumption or for processing purposes after 14, 7 and 3 days of the spraying of imidacloprid, diniconazole and etoxazole, respectively.

The average removal percentages of imidacloprid, diniconazole and etoxazole residues in strawberry fruits, juice, syrup cold and hot break are higher than that of unwashed strawberry fruits. Moreover, strawberries syrup under hot break reduced the amount of the three pesticide residues, which were higher than with strawberries syrup under cold break (Tables 1, 2 and 3). Results revealed that residues of imidacloprid, etoxazole and diniconazole, after juicing operation reached the levels of $1.2,0.035$ and $0.03 \mathrm{ug} / \mathrm{ml}$ indicating 25, 36.37 and 88.64 $\%$ reduction after 3 days respectively. While, found to be $0.52,0.02$ and 0.02 $\mathrm{ug} / \mathrm{ml}$ indicating 32.45, 47.37 and $86.67 \%$ dislodging respectively after 7 days of spraying. This results indicated that imidacloprid residue was concentrated in juice higher than that etoxazole and diniconazole, this may be due to Physicochemical properties of imidacloprid., high water solubility $(600 \mathrm{mg} / \mathrm{L})$ and low Octanol-water coefficient (Kow), $\log \mathrm{P}=0.57$ at $21{ }^{\circ} \mathrm{C}$ ), while the water solubility and Kow of diniconazole and etoxazole were $4 \mathrm{mg} / \mathrm{L}$ 
(Kow, $\log \mathrm{P}=4.3$ at $25{ }^{\circ} \mathrm{C}$ ) and $75.4 \mu \mathrm{g} / \mathrm{L}\left(\right.$ Kow, $\log \mathrm{P}=5.59$ at $25{ }^{\circ} \mathrm{C}$ ), respectability (Tomlin, 2004). The residue levels in juices from strawberry fruits depend on the partitioning properties of the pesticide between the fruit skin/pulp and the juice. The pulp which often includes the skin retains a substantial proportion of lipophilic residues. Thus moderately to highly lipophilic pesticides are poorly transferred into juices and the residues are further reduced by clarification operations such as centrifugation or filtering (Holland et al., 1994).

After 3 and 7 days, the reduction percentage of imidacloprid, diniconazole and etoxazole residues reached to 39.37-44.16\%, 27.28-34.21\% and $69.23-80.0 \%$ in strawberries syrup under cold break while it increased, respectively, to $42.50 \%-50.64 \%, 51.51 \%-54.55 \%$ and $76.92 \%-93.33 \%$ under hot break (Tables 1, 2 and 3). The rate of dislodging of residues due to factors like temperature, duration of the process, the amount of water, food additives and the type of system (open/closed) (Angioni et al., 2004). The elevated values of pesticide reduction at hot break could be due to the following; first the heat pretreatment of strawberry fruits; second the removal of the fruit rinds in which the pesticide residues were possibly concentrated during straining and third the post-heat preservation treatment $(90 \mathrm{C}$ for $15 \mathrm{~min}$ ) of the pasteurized resulting juice (Ramadan, 1990).

In Tables 1, 2 and 3, it was evident that, when strawberry fruits were processed into Jam, imidacloprid, diniconazole and etoxazole residues were concentrated and increased to higher levels than those in the strawberry juice. The relatively high residue levels in juicing by-products can undergo further increases upon drying due to the simple loss of moisture (Holland et al. , 1994). This indicates that the concentration process had raised the pesticide residues in the final product. This is quite expected because of the concentration step that transforms the juice into a Jam. This was evident despite the possible destructive or reductive effect of both heat treatments carried out to convert strawberry juice into strawberry Jam and the final treatment of the jam, after being packed in the containers (bottles, processed at 90_C for $15 \mathrm{~min}$ ) for the final preservation (Ramadan, 1990). Open systems may result in water loss during heating by evaporation, thereby concentrating the pesticide residues if they are not destroyed by heating (Abou-Arab, 1999). The processes that normally occur during cooking are volatilization, hydrolysis and thermal breakdown (AbouArab, 1999; Balinova et al., 2006 and Stepan et al., 2005).

Results of chemical analysis of strawberry fruits and strawberry products treated with imidacloprid, diniconazole and etoxazole after 7 days of spray time and in untreated control are shown in Table 4. After 7 days of spray time with three pesticides, the average total soluble solids (TSS) were decreased in strawberry juice compared with other samples. Total sugars were increased in 
Table 4. Changes in physical and chemical characteristics of strawberry products treated with imidacloprid, diniconazole and etoxazole after 7 days of spray time

\begin{tabular}{|c|c|c|c|c|c|c|}
\hline Items & $\mathbf{T S S} \dot{P}^{\circ}(\mathbf{B X})$ & $\begin{array}{l}\text { Reducing } \\
\text { Sugars } \\
\text { (g/100ml } \\
\end{array}$ & $\begin{array}{l}\text { Total } \\
\text { acidity } \\
\text { (citric) }\end{array}$ & $\begin{array}{l}\text { Ascorbic } \\
\text { acid } \\
(\mathrm{g} / 100 \mathrm{ml}) \\
\end{array}$ & $\begin{array}{c}\mathrm{PH} \\
\text { value }\end{array}$ & $\begin{array}{l}\text { Crude } \\
\text { protein } \\
(\mathrm{g} / 100 \mathrm{ml})\end{array}$ \\
\hline \multicolumn{7}{|c|}{ Juice } \\
\hline Control & $\begin{array}{c}7.0 \\
\pm 0.76\end{array}$ & $\begin{array}{c}4.25 \\
\pm 0.21\end{array}$ & $\begin{array}{c}0.72 \\
\pm 0.35\end{array}$ & $\begin{array}{c}50.4 \\
\pm 0.35\end{array}$ & $\begin{array}{c}3.21 \\
\pm 0.11\end{array}$ & $\begin{array}{c}0.25 \\
\pm 0.03\end{array}$ \\
\hline $\begin{array}{c}\text { Imidacloprid } \\
+ \text { S.D }\end{array}$ & $\begin{aligned} & 7.5 \\
+ & 0.66\end{aligned}$ & $4.133 \pm 0.60$ & $\begin{array}{c}0.79 \\
+0.48\end{array}$ & $\begin{array}{c}60.0 \\
+0.61\end{array}$ & $\begin{array}{c}3.21 \\
+0.15\end{array}$ & $\begin{array}{c}0.24 \\
+0.02\end{array}$ \\
\hline Diniconazole & 7.1 & $4.253 \pm 0.42$ & 0.74 & 61.0 & 3.24 & 0.24 \\
\hline \pm S.D & \pm 0.98 & & \pm 0.50 & \pm 0.48 & \pm 0.21 & \pm 0.03 \\
\hline $\begin{array}{l}\text { Etoxazole } \\
\quad \pm \text { S.D }\end{array}$ & $\begin{array}{r}7.05 \\
\pm 0.41\end{array}$ & $4.003 \pm 0.41$ & $\begin{array}{c}0.62 \\
\pm 0.42\end{array}$ & $\begin{array}{r}58.0 \\
+0.60\end{array}$ & $\begin{array}{c}3.16 \\
\pm 0.26\end{array}$ & $\begin{array}{r}0.26 \\
+0.04\end{array}$ \\
\hline \multicolumn{7}{|c|}{ syrup cold } \\
\hline $\begin{array}{c}\text { Control } \\
\pm \text { S.D }\end{array}$ & $\begin{array}{l}60.0 \\
\pm 0.53\end{array}$ & $\begin{array}{l}15.50 \\
\pm 0.38\end{array}$ & $\begin{array}{c}1.41 \\
\pm 0.53\end{array}$ & $\begin{array}{c}42.7 \\
\pm 0.41\end{array}$ & $\begin{array}{c}3.3 \\
\pm 0.10\end{array}$ & $\begin{array}{c}0.29 \\
\pm 0.02\end{array}$ \\
\hline $\begin{array}{c}\text { Imidacloprid } \\
\pm \text { S.D }\end{array}$ & $\begin{array}{c}60.0 \\
\pm 0.93\end{array}$ & $11.63 \pm 0.23$ & $\begin{array}{c}1.22 \\
\pm 0.43\end{array}$ & $\begin{array}{l}33.65 \\
\pm 0.53\end{array}$ & $\begin{array}{c}3.3 \\
\pm 0.32\end{array}$ & $\begin{array}{c}0.29 \\
\pm 0.04\end{array}$ \\
\hline Diniconazole & 60.0 & $11.42 \pm 0.71$ & 1.33 & 33.43 & 3.3 & 0.27 \\
\hline \pm S.D & \pm 0.60 & & \pm 0.47 & \pm 0.25 & \pm 0.16 & \pm 0.02 \\
\hline Etoxazole & 60.0 & $10.55 \pm 0.33$ & 1.2 & 34.21 & 3.3 & 0.26 \\
\hline \pm S.D & \pm 0.82 & & \pm 0.53 & \pm 0.13 & \pm 0.12 & \pm 0.02 \\
\hline \multicolumn{7}{|c|}{ syrup hot } \\
\hline $\begin{array}{c}\text { Control } \\
\pm \text { S.D }\end{array}$ & $\begin{array}{c}60.0 \\
\pm 0.59\end{array}$ & $45.90 \pm 0.28$ & $\begin{array}{c}1.45 \\
\pm 0.40\end{array}$ & $\begin{array}{l}17.20 \\
\pm 0.10\end{array}$ & $\begin{array}{c}3.3 \\
\pm 0.15\end{array}$ & $\begin{array}{c}0.36 \\
\pm 0.18\end{array}$ \\
\hline $\begin{array}{c}\text { Imidacloprid } \\
\pm \text { S.D }\end{array}$ & $\begin{array}{l}60.0 \\
\pm 0.87\end{array}$ & $46.51 \pm 0.32$ & $\begin{array}{c}1.3 \\
\pm 0.25\end{array}$ & $\begin{array}{l}11.65 \\
\pm 0.15\end{array}$ & $\begin{array}{c}3.34 \\
\pm 0.38\end{array}$ & $\begin{array}{c}0.31 \\
\pm 0.43\end{array}$ \\
\hline Diniconazole & 60.0 & $46.25 \pm 0.15$ & 1.32 & 11.42 & 3.34 & 0.31 \\
\hline \pm S.D & \pm 0.95 & & \pm 0.23 & \pm 0.12 & \pm 0.26 & \pm 0.03 \\
\hline Etoxazole & 60.0 & $45.19 \pm 0.39$ & 1.28 & 10.55 & 3.34 & 0.36 \\
\hline \pm S.D & \pm 0.59 & & \pm 0.56 & \pm 0.15 & \pm 0.31 & \pm 0.01 \\
\hline \multicolumn{7}{|c|}{ jam } \\
\hline Control & 68 & 54.30 & 1.51 & 18.2 & 3.35 & 0.57 \\
\hline \pm S.D & \pm 0.66 & \pm 0.27 & \pm 0.86 & \pm 0.13 & \pm 0.20 & \pm 0.02 \\
\hline Imidacloprid & 68 & 57.00 & 1.4 & 19.23 & 3.35 & 0.67 \\
\hline \pm S.D & \pm 0.15 & \pm 0.29 & \pm 0.21 & \pm 0.17 & \pm 0.10 & \pm 0.03 \\
\hline Diniconazole & 68 & 52.40 & 1.51 & 18.2 & 3.35 & 0.94 \\
\hline \pm S.D & \pm 0.60 & \pm 0.48 & \pm 0.17 & \pm 0.21 & \pm 0.10 & \pm 0.02 \\
\hline Etoxazole & 68 & 46.7 & 1.51 & 17.22 & 3.35 & 0.65 \\
\hline \pm S.D & \pm 0.35 & \pm 0.47 & \pm 0.25 & \pm 0.18 & \pm 0.16 & \pm 0.04 \\
\hline
\end{tabular}


syrup hot and jam than other treatment. This increment may be explained in syrup hot and jam by dissolving sucrose with citric acid and heating, result increase glucose and fructose (reducing sugars). Total sugars were decreased in syrup cold under treatment with three pesticides than control samples. Otherwise, ascorbic acid content in syrup hot and jam were decreased comparison with the other samples. The heating process exposed ascorbic acid to degradation. Also, minor differences in ascorbic acid under treatment with three pesticides in syrup hot and cold when compared with result of control (Table 4). Strawberries are a good source of ascorbic acid (vitamin C) which is a very important nutrient, being essential, e.g. for the synthesis of collagen. Ascorbic acid is also a natural antioxidant used in foodstuff formulations in order to prevent browning, discoloring and to enhance shelf life (Castro et al., 2004).

Conclusively, data showed that the changes in physical and chemical properties of strawberry fruits and products was related mainly to the processing operations. ( Cordenunsi et al., 2003 \& 2005; Sandra et al., 2006; Mehmet and Haydar ., 2007).

\section{REFERENCES}

A.O.A.C. (1995). Association of Official Analytical Chemists. Official Methods of Analysis, [16 thed.] A.O.A.C. International, Artligton, Virginia,USA.

Abou-Arab, A.A.K. and Abou Donia, M.A. (2001). Pesticide residues in some Egyptian spices and medicinal plants as affected by processing. Food Chemistry $72: 439-445$.

Angioni, A. Schirra, M., Garau, V. L.., Melis, M., Tuberoso, C. I. G. and Cabras P. (2004). Residues of azoxystrobin, fenhexamid and pyrimethanil in strawberry following field treatments and the effect of domestic washing. Food Additives and Contaminants, 21: 11, 10651070.

Bai, D., Lummis, S.C.R., Leicht, W., Beer, H. and Sattelle, B.D. (1991). Action of imidacloprid and a related nitromethyl on cholinergic receptors of an identified insect motor neurone. Pest. Sci., 33:197-204.

Balinova, A.M., Mladenova, R.I. and Shtereva, D.D.( 2006). Effects of processing on pesticide residues in peaches intended for baby food. Food Additives and Contaminants $23: 895-901$.

Byrne, S. L. and Pinkerton, S. L. (2004). The effect of cooking on chlorpyrifos and 3,5,6- trichloro-2-pyridinol levels in chlorpyrifos-fortified produce for use in refining dietary exposure. Journal of Agricultural and Food Chemistry, 52, 7567-7573. 
Castro I., Teixeira J. A., Salengke S., Sastry S. K. and Vicente A. A. (2004). Ohmic heating of strawberry products: electrical conductivity measurements and ascorbic acid degradation kinetics. Innov. Food Sci. Emerg. Tech. 5:27-36.

Chai, M. K. and Tan G. H. (2010). Headspace solid-phase micro extraction for the evaluation of pesticide residue contents in cucumber and strawberry after washing treatment. Food Chemistry, 123:760-764.

Cordenunsi, B. R., Nascimento, J. R. O. and Lajolo, F. M. (2003). Physicochemical changes related to quality of five strawberry fruit cultivars during cool-storage. Food Chemistry, 83, 167-173.

Cordenunsi, B. R., Genovese, M. I., Nascimento, J. R. O., Hassimotto, N. M. A., Santos, R. J. and Lajolo, F. M.(2005). Effects of temperature on the chemical composition and antioxidant activity of three strawberry cultivars. Food Chem.,91: 113-121.

Falqui-Cao, C., Wang, Z., Urruty, L., Pommier, J.-J. and Montury, M.(2001). Focused microwave assistance for extracting some pesticide residues from strawberries into water before their determination by SPME/HPLC/DAD. Journal of Agriculture and Food Chemistry, 49: 5092-5097.

FAO/WHO (2008). Codex alimentarius. Pesticide residues in food. Maximum residue limits. 9 April, Rome, Italy.

Gomaa, E. A. A. and Belal, M. H. (1975). Determination of dimethoate residues in some vegetable and cotton plant. Zagazig, J., Agric. Res. 2, 215-221.

Guardia-Rubio, M., Ayora-Canada, M.J. and Ruiz-Medina, A. ( 2007). Effect of washing on pesticide residues in olives. Journal of Food Science ,72: C139-C143.

Holland, P.T., Hamilton, D., Ohlin, B. and Skidmore, M.W. (1994). Effects of storage and processing on pesticide residues in strawberry plant products. Pure Appl Chem .,66:335-356

Kaushik, G., Satya, S. and Naik, S.N.(2009). Food processing a tool to pesticide residue dissipation - a review. Food Research International ,42:26-40.

Keikotlhaile, B.M. , Spanoghe, P. and Steurbaut, W.( 2010). Effects of food processing on pesticide residues in fruits and vegetables: A metaanalysis approach. Food and Chemical Toxicology, 48 : 1-6.

Khay S, Choi J.H. and Abd El-Aty MA (2008). Dissipation behavior of lufenuron, benzoylphenylurea insecticide, in/on Chinese cabbage applied by foliar spraying under greenhouse conditions. Bull Environ Contam Toxicol, 81:369-372. 
Kousik, M., Chahi. G. S., Sahoo , S. K., Battu, R. S. and Balwinder, S. (2010). Dissipation Kinetics of b-Cyfluthrin and Imidacloprid in Brinjal and Soil Under Subtropical Conditions of Punjab, India. Bull Environ Contam Toxicol ., 84:225-229.

Luke, M. A., Froberg, J. E., Doose, G. M. and Masumato, H. T. (1981). Improved Multiresidue GasChromatographic Determination of Orgonophosphorus, Orgononitrogen and Orgonohalogene Pesticides in Procedure, Using Flame Photometric and Electrolytic Conductivity Detectors, JAOAC.64, 1187-1195.

Ozcan, M.M. and Haciseferogullari, H.( 2007). The Strawberry (Arbutus unedo L.) fruits: Chemical composition, physical properties and mineral contents. Journal of Food Engineering .78:1022-1028.

Mohamed M. A, Mostafa A. S, Hayam M. L. and Hany H. M (2007). Determination of Tetraconazole and Diniconazole Fungicide Residues in Tomatoes and Green Beans by Capillary Gas Chromatography. Yakugaku Zasshi ,127,6: 993-999.

Ramadan, R.A. (1990). Residues of profenofos and pirimiphos methyl in tomato and okra fruits as influenced by certain technological processes. 4th Natural Control of Pests and Diseases in Vegetables And Fruits in Egypt

Ramadan, R.A.; Koriem ,A.M; Mostafa,A.M. and Khafagi, Y.S. (1992). Efficiency of some fungicides in controlling strawberry powdery mildew and their residues in the fruits .Egypt .J.Appl.Sci.,7:(11) 1-12

Ripley, B.D. and Edgington, L.V. (1983). International and external plant residues and relationships to activity of pesticides. Plant protection for human welfare, 10th. International congress of plant protection (Croydon England British Crop Protection Council) 2:545-553

Sandra, V., Boris, D., Jasmina, D., Martina, S. B., Nadica, D. and Zlatko, Č. (2006). Influence of Cultivation Systems on Physical and Chemical Composition of Strawberry Fruits cv. Elsanta Agriculturae Conspectus Scientifi cus, $71: 171-174$.

Sanyal, N., Hazra, D., Pal, R., Somchaudhury, A. K. and Chowdhury, A. (2006). Imidacloprid in processed tea and tea liquor. Journal of Zhejiang University SCIENCE. 7B(8): 619-622.

Shibuya, I. (1999). Baroque (Etoxazole) a new selective acaricide. Agrochem. Japan 18:18-19.

Shweta W., Pinky B. and Beena K .(2010). Effect of Processing on Dislodging of Cypermethrin Residues on Brinjal. Bull Environ Contam Toxicol $., 84: 465-468$. 
Stensvand, A. and Christiansen, A. (2000). Investigation on fungicide residues in greenhouse-grown strawberry. Journal of Agriculture and Food Chemistry, 48, 917-920.

Štepán R., Tichá J., Hajšlová J., Kovalczuk T. and Kocourek V. (2005). Baby food production chain: Pesticide residues in fresh apples and products. Food Addit. Contam. 22, 1231-1242, IF:1,810

Tomizawa, M. and Yamamoto, I. ( 1993). Structure activity relationship of nicotinoids and imidacloprid analogues. J. Pest. Sci., 18:91-98.

Tomlin, C. (2004). The pesticide Manual, 13 th ed. British Crop Protection council, Farniham, surey, UK. PP. 267,320,458.

Waller, R.A. and Duncan, D.P. (1969). A bays rule for symmetric multiple comparison problem. Amer. Stat. Assoc. J. December, 1485-1503.

Wennrich, L., Popp, P., Koller, G. and Breuste, J. (2001). Determination of organochlorine pesticides and chlorobenzenes in strawberries by using accelerated solvent extraction combined with sorbitive enrichment and gas chromatography/ mass spectrometry. Journal of AOAC International, 84, 1194-1201.

Will, F. and Kruger, E. (1999). Fungicide residues in strawberry processing. Journal of Agriculture and Food Chemistry, 47, 858-861.

Yun, L., Hanm W., Wei, Y., Feng, Z., Li, S., Min-Li, Y., Yong-Ning ,W. and Xiao-Gang, C.(2011). The effects of washing and cooking on chlorpyrifos and its toxic metabolites in vegetables. Food Control ,22, 54-58. 
تأثير التصنيع الغذائي على متبقيات الاميدا كلوبرايد والداى نيكونازول

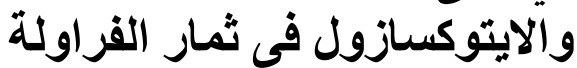

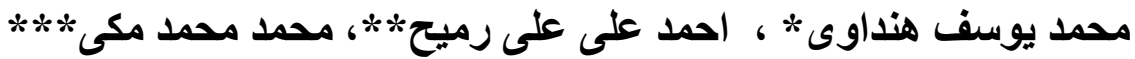

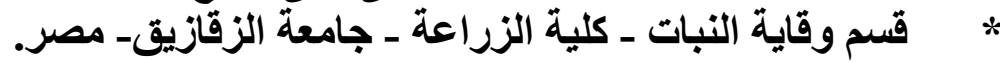

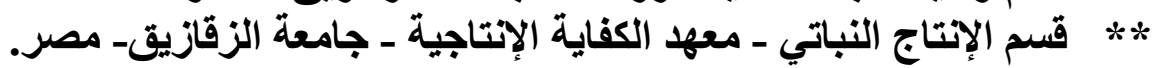

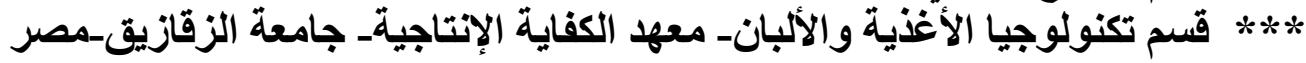

تـم رش ثمـار الفراولـة بثلاثـة مركبـات هـى الاميـا كلوبرايــ والـداى نيكونـازول و الايتوكسازول بالمعدلات الموصى بها.درس تأثير العمليات التصنيعية المختلفة على إزالة متبقيات المبيدات المختبرة ـ طبقا لفترة نصف العمر يمكن تحديد ميعاد الحصاد بهاد

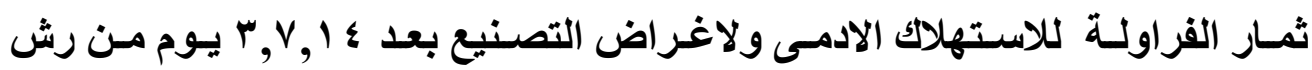
مبيدات الاميذا كلوبرايد والداى نيكونازول و الايتوكسازول على التوالي ـ كاتت نسبة الخفض في متبقيات مبيدات الاميدا كلوبرايد والداى نيكونازول و الايتوكسازول في

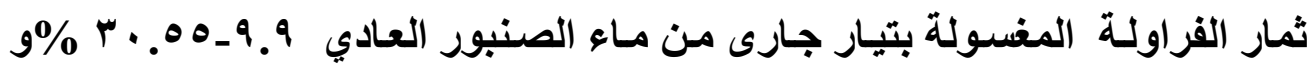

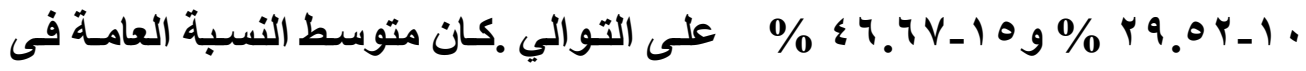
خفض متبقي الثُلاث مبيدات المختبرة في الثمار الطازجة وفى العصير والثراب على البارد والساخن عالي مقارنة بالثمار الغير مغسولة.

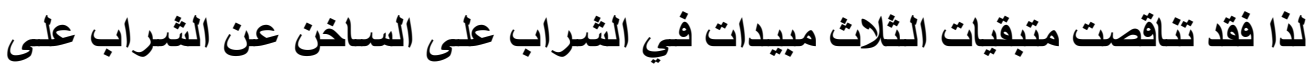
البارد وتركزت متبقيات المبيدات الثلاثة في المربى عن العصير. ترجع التغيرات الفيزيقية والكيمائية في ثمار الفراولة والمنتجات المصنعة إلى تأثير عمليات التصنيع 